\title{
Knowledge of Sickle Cell Disease and Haemoglobin Electrophoresis: A Survey of Students of a Tertiary Institution
}

\author{
*Alao $00, M B ; c h B, F W A C P\left(L a b\right.$ Med) ${ }^{* *}$ Araoye M , MBBS, FWACP \\ ${ }^{* * *}$ Ojabo, C MBBS, FWACS
}

\begin{abstract}
Background: Sickle Cell Disease (SCD) is the commonest genetic disease worldwide. Of the sickle cell control strategies, premarital genetic counselling is increasingly practised in many countries of the world. Knowledge of the citizenry of a nation about SCD constitutes an important variable that influences the acceptability, practice and success of premarital genetic counselling. A study of students of Benue State University, Makurdi was carried out to determine their current level of knowledge.
\end{abstract}

Method: A cross sectional study involving 300 students of Benue State University, Makurdi; selected by a multistage stratified sampling technique, using self administered structured questionnaire, was carried out.Results: Virtually all study respondents had at one time or the other heard about sickle cell disease. Based on the criteria used for knowledge scoring, less than half of the students (48\%) demonstrated good knowledge. Overall Mean Score Knowledge (MSK) was 4.65 1.65. MSK was $4.58 \pm 1.66$ and $4.74 \pm 1.64$ for males and females respectively; there was no statistically significant difference ( $P>0.05)$. However, having an affected relative suffering from sickle cell disease significantly influenced level of knowledge among study respondents $(P<0.05)$, but was not significantly associated with respondents knowing their haemoglobin phenotype. Only 141 students (47\%) knew their haemoglobin phenotype. Level of knowledge about SCD did not significantly increase with age. Also, sex and religion did not significantly influence level of knowledge.

Conclusion: The knowledge about SCD was poor and only a few knew their haemoglobin phenotype. If sickle cell disease control strategies must yield any significant results, more education about SCD, especially among students in tertiary institutions in Nigeria is recommended. The use of persons with SCD as peer educators/counsellors should be explored.

Key Words: Knowledge, sickle cell disease, tertiary institution

\footnotetext{
Date Accepted for publication: 11th June 2009

Nig J Med 2009;

Copyright $@ 2009$ Nigerian Journal of Medicine
}

\section{INTRODUCTION}

Sickle cell disease includes a variety of combinations in which the sickle cell gene is present with another abnormal gene resulting in abnormality of haemoglobin structure and production. The sickle cell anaemia $(\mathrm{Hb}$ $\mathrm{SS}$ ), the sickle cell haemoglobin C disease ( $\mathrm{Hb} \mathrm{SC}$ ), and sickle cell $\beta$ thalassaemia ( $\mathrm{Hb} S \beta$ thal) are three common variants of sickle cell disease in Africa. ${ }^{1,2} \mathrm{About}$ $25 \%$ of people of African stock carry the sickle cell gene, while only $23 \%$ suffer from sickle cell disease. The commonest sickle cell disease in Nigeria is sickle cell anaemia (Hb SS) with an estimated prevalence of $13 \%$. Affected patients are high risk groups with significant morbidity and mortality. The condition also places a severe burden on relatives and families of affected persons $^{3}$

In the absence of curative therapy, the subject of prevention and control of sickle cell disease will continue to attract much attention of scholars. The control of sickle cell disease through Prenatal Diagnosis (PND) and premarital genetic counselling have both been practised in many countries of the world for many years. While PND is a recent phenomenon in Nigeria ${ }^{4-6}$, premarital genetic counselling may have come a long way.

However, in many instances, there are no well organized and identified genetic counselling clinics and centres. Without any doubt, the awareness, acceptability, practice, sustenance and success of premarital genetic counselling as a control strategy for SCD will depend on the level of knowledge that a nation's citizenry has on sickle cell disease. As a matter of fact, in order to have the basis on which to plan and modify current /existing strategies on SCD control and prevention, the knowledge of students of tertiary institutions (who are by all probabilities likely to go into marriage sooner than later) and the factors influencing it are essential. It is believed that these students constitute an important population group towards which major policy issues and strategies can be channeled positively towards sickle cell disease control. They are therefore viewed as positive assets to sickle cell disease prevention. 
Various studies have revealed varying levels of knowledge on SCD among studied groups in Nigeria and elsewhere $^{8-11 .}$ To the best of the authors' knowledge, there are no statistics available from Makurdi, in middle belt region of Nigeria. This study therefore aims at determining the level of knowledge of SCD among students attending a tertiary institution in Makurdi, and to identify the factors that influence knowledge.

\section{Materials and Methods}

The study was conducted in April 2008 in the metropolis of Makurdi. Single, unmarried students of the Benue State University were enrolled in the study. Approval for the study was obtained from the University Ethical Committee and informed consent from the respondents. The number of students studied was 300 . A multistage sampling method was used to select this sample size from the various departments in the university. The instrument used for the study was a structured pretested questionnaire designed to elicit socio-demographic data, as well as the knowledge of students on sickle cell disease and haemoglobin electrophoresis. The data was analysed using statistical package for social science (SPSS) for windows. The descriptive statistics were obtained.

To determine students' level of knowledge on SCD, knowledge scores were computed on eight questions in the questionnaire which assessed their knowledge on SCD. One mark was given for each correct answer. Maximum obtainable score was eight. Those who scored less than 5 were graded to have poor knowledge; and 58 good knowledge.

\section{RESULTS}

Three hundred and twenty (320) students participated in the study. Information from 20 students $(6.25 \%)$ who completed the questionnaire wrongly was not included in the analysis. Data from 300 students were therefore analysed.

\section{Background characteristics of students}

The age and sex distributions of the study group are shown in Table 1. One hundred and eighty students (60\%) were male while 120 were female $(40 \%)$. The overall mean age of the study population was $23.09 \pm 3.93$ (age range $=16$ to 35 years). The modal age bracket was 20 24 years. Majority of the students (two hundred and sixty eight, representing 89\%) were Christians, while 32 students (11\%) were Muslims.

\section{Source of information}

All respondents affirmed that they had indeed heard of sickle cell disease at one time or the other before. One hundred and thirty nine respondents heard of sickle cell disease via a friend / relative (46\%), $61(20.2 \%)$ heard of the disease through the media/newspaper, 54 (17.9\%) through health workers, 22 (7.3\%) through books /lectures in classrooms and $10(3.3 \%)$ through sickle cell counsellors. Majority of the students (82\%) were able to correctly identify SCD as a hereditary condition. 269 students (89.1\%) believed both parents are involved in transmission of sickle cell disease to off springs, 14 students (4.6\%) believed only the mother is involved; and 10 students (3.3\%) believed only the father is involved.

\section{Knowledge of SCD \& haemoglobin phenotype}

On whether sickle cell disease can be prevented or controlled, 259 students (85.8\%) indicated that it can be prevented. Concerning the methods / measures of control, 178 students (59\%) correctly identified genetic counselling and or prenatal diagnosis as the control strategies. Most students (94.4\%) responded that the best time for genetic counselling was during courtship. When asked the commonest presenting symptom of sickle cell disease, 217 students (71.9\%) correctly identified pain, as the commonest presenting symptom. As seen in Table 2, 247 students (82\%) correctly identified SCD to be inheritable. Less than half, 141 students $(47 \%)$ knew their haemoglobin electrophoresis status while 159 students $(53 \%)$ did not know theirs (see table 3). Of those who had an affected relative, less than half (48.7\%) knew their haemoglobin phenotype. Having an affected relative did not significantly influence respondents' knowledge of their phenotype. $(P>0.05)$

The overall Mean Score Knowledge (MSK) of the students about SCD was $4.65 \pm 1.65$. The relationship between level of students' knowledge and certain identified variables is shown in Table 4. The level of knowledge of the students about SCD was not associated with age $(P>0.05)$. The MSK of SCD was $4.58 \pm 1.66$ and $4.74 \pm 1.64$ for males and females respectively. The difference was not statistically significant $(P>0.05)$.

The mean score knowledge was $4.63 \pm 1.67$ and $4.75 \pm 1.52$ for Christian and Muslim respondents respectively. The difference was not statistically significant. 


\section{DISCUSSION}

Sickle cell anaemia contributes to equivalence of $5 \%$ of under-five deaths on the African continent, more than $9 \%$ of such deaths in West Africa, and up to $16 \%$ of under-five deaths in individual West African countries. ${ }^{12}$ Sickle cell disease therefore poses serious health concern, especially in developing countries. If SCD control programs must yield positive results, knowledge and awareness of residents of every country about sickle cell disease are viewed as important variables.

It is quite remarkable that this study revealed that virtually all the study respondents had at one time or the other heard about sickle cell disease. This is not entirely surprising, and may be attributable to the high sickle cell disease prevalence rate in Nigeria, so much so that almost every individual must have either encountered an affected person, or heard about the condition in one way or the other. It was however noted that less than half $(47 \%)$ of the study respondents had good knowledge of SCD. This figure is at variance with similar studies conducted elsewhere in Nigeria. ${ }^{7,8}$ A study to examine the knowledge of students of University of Ibadan about SCD revealed that $63.6 \%$ of respondents have good knowledge $^{8}$, while Adeyemo documented that $86 \%$ of randomly selected persons in University of Lagos community have a good knowledge about $\mathrm{SCD}^{7}$. It was however observed that the University of Lagos survey was among randomly selected members of the University community, and not particularly among students. Our finding of deficient knowledge in more than half of the study respondents is similar to the results of a study conducted among new graduates of Nigerian tertiary institution by Adewuyi et al in llorin ${ }^{10}$. A good knowledge rate of $47 \%$ obtained in this study has far reaching implications on SCD control strategies. It is worthy of note that all study respondents were students and single. If this

\section{References}

1. Mabayoje $\mathrm{J}$ O. Sickle cell anaemia: A major disease in West Africa. Brit Med J. 1956; 1: 194-6

2. Konotey-Ahulu FID.The Sickle Cell Disease Patient.London: Macmillan; 1991.34-40.

3. Oyedeji GA.The effects of sickle cell disease on the families of affected children (letter).Central Afr Med J.1995;41(10):333334

4. Hobbins JC, Mahony MJ. In utero diagnosis of Haemoglobinopathies:techniques for obtaining foetal blood Engl J Med.1974;290:1065-1067

5. Loader S, Sutera CJ, Walden M, Kozra A, Roley PT.Prenatal screening for Haemoglobinopathies II:Evaluation of counseling. Am J Human Genet.1991;48:447-51 knowledge assessment is viewed critically against the worrisome proportion of students who did not know their haemoglobin phenotype (48\%), one may likely assess or view any existing genetic counselling strategies as well as other sickle cell education programs as not yet yielding the desired effect or results in Nigeria. Considering that a good number of these students are likely to be in one form of relationship or the other, we hasten to emphasize that early haemoglobin electrophoresis testing among young adults is central to SCD control. This will avoid late detection of genetic incompatibilities among intending couples with its attendant numerous problems and complexities.

Our study showed that having an affected relative with sickle cell disease significantly influenced level of knowledge $(P<0.05)$. This is not surprising, as family members with affected patients are more commonly involved in the overall support, care and rehabilitation and therefore naturally end up knowing more about the condition, compared to respondents without affected relatives. One would also naturally expect such respondents with affected relatives to have checked and known their status. It is however rather surprising that only $48.7 \%$ of those who had an affected relative actually knew their status (in contrast to $45.8 \%$ of those without an affected relative). A lot of individuals believe that features of SCD typically start to manifest in childhood, and most adults do not bother to check their haemoglobin phenotype thinking that they are not likely to be sicklers at such advanced age.

In conclusion, our study showed that less than half of the study respondents had good knowledge about SCD and knew their haemoglobin phenotype. More education about SCD, especially for students in tertiary institutions in Nigeria is recommended. The use of persons with SCD as peer educators/counsellors should be explored.
6. Durosimi MA,Odebiyi Al, Akinola NO, Et al.Acceptability of Prenatal diagnosis of sickle cell anaemia by a sample of the Nigerian population. Afr J Med Sci.1997;26(1-2):55-58

7. Adeyemo M, Oyenike A, Omidiji B, Oluseun O.Level of awareness of genetic counseling in Lagos, Nigeria.lts advocacy on the inheritance of sickle cell disease.Afr $\mathrm{J}$ of Biotechnology.2007;6(24):2758-2765

8. Moronkola OA, Fadairo RA.University students in Nigeria: knowledge and attitude towards sickle cell disease and genetic counseling before marriage. International quarterly of community health education.2007;26:85-93

9. Creary M, Williamson D, Kulkarni R. Sickle cell disease: current activities, public health implications, and future directions. J Womens Health (Larchmt). 2007 Jun; 16(5):575-82. 
10. Adewuyi JO. Knowledge of and attitudes to sickle cell disease and sickle carrier screening among new graduates of Nigerian tertiary educational institutions. Niger Postgrad Med J. 2000 Sep; 7(3):120-3.

\section{Table 1:Age \& Sex Distribution of respondents}

\begin{tabular}{cccccc}
\hline \multicolumn{7}{c}{ GENDER } \\
$\begin{array}{c}\text { Age group } \\
\text { (Years) }\end{array}$ & No. & $\begin{array}{c}\text { Male } \\
(\%)\end{array}$ & No. & $\begin{array}{c}\text { Female } \\
(\%)\end{array}$ & $\begin{array}{c}\text { Total } \\
\text { No. }\end{array}$ \\
\hline & & & & & \\
$<20$ & 31 & $(17.2)$ & 21 & $(17.5)$ & 52 \\
20 & 68 & $(37.7)$ & 85 & $(70.8)$ & 153 \\
25 & 60 & $(33.3)$ & 7 & $(5.8)$ & 67 \\
$>30$ & 21 & $(11.7)$ & 7 & $(5.8)$ & 28 \\
Total & 180 & $(60.0)$ & 120 & $(40.0)$ & 300 \\
\hline
\end{tabular}

Table 2: Students' understanding of the aetiology of SCD by Gender

\begin{tabular}{lccc}
\hline \multicolumn{1}{c}{ Aetiology } & Male (\%) & Female (\%) & Total \\
\hline Infection & $13(7.2)$ & $16(13.3)$ & 29 \\
Inherited & $159(88.3)$ & $88(73.3)$ & 247 \\
Cancer & - & - & - \\
Witchcraft & $2(1.1)$ & - & 2 \\
Not sure & $6(3.3)$ & $11(9.2)$ & 17 \\
Dont know & - & $5(4.2)$ & 5 \\
Total & $180(100)$ & $120(100)$ & 300 \\
\hline
\end{tabular}

Table 3: Knowledge of Respondents' Haemoglobin electrophoresis by Gender and having relative with SCD.

\begin{tabular}{l|c|c|c}
\hline \multicolumn{3}{c}{ Hb Electrophoresis status } \\
$(\%)$ \\
\hline \multirow{2}{*}{${ }^{*}$ Gender } & Known & Not Known & Total \\
Female & $82(45.6)$ & $98(54.4)$ & 180 \\
TOTAL & $59(49.2)$ & $61(50.8)$ & 120 \\
\hline${ }^{* *}$ Having a relative with & 141 & 159 & 300 \\
$\quad$ SCD: & & & \\
\hline Have relative with SCD & & & 123 \\
$\begin{array}{l}\text { Dont have relative with SCD } \\
\text { TOTAL }\end{array}$ & $60(48.7)$ & $63(51.3)$ & 177 \\
& $81(45.8)$ & $96(54.2)$ & 300 \\
\hline
\end{tabular}

${ }^{*} X^{2}=0.375 d f=1, P>0.05{ }^{*} X^{2}=0.364 d f=1, P>0.05$
11. Boyd JH, Watkins AR, Price CL, Fleming F, DeBaun MR. Inadequate community knowledge about sickle cell disease among African-American women. J Natl Med Assoc. 2005 Jan; 97(1):62-7.

12. World Health Organization (WHO) (2005) Sickle cell Anaemia.Executive Board $117^{\text {th }}$ session Provisional Agenda item, 4.8.EB 117/34

Table 4: Relationship between knowledge status and some variables.

\begin{tabular}{|c|c|c|c|c|c|c|}
\hline Variable & $\begin{array}{l}\text { Gooc } \\
\text { No }\end{array}$ & $\begin{array}{l}\text { nowledge } \\
\text { (\%) }\end{array}$ & \multicolumn{2}{|c|}{$\begin{array}{l}\text { Poor } \\
\text { knowledge }\end{array}$} & $P$-value & Total \\
\hline \multicolumn{7}{|l|}{ Age: } \\
\hline$<20$ & 24 & (46.2) & 28 & 53.8 & \multirow{4}{*}{$P>0.05$} & 52 \\
\hline $20 \quad 24$ & 84 & (54.9) & 69 & 45.1 & & 153 \\
\hline $25 \quad 29$ & 24 & (35.8) & 43 & 64.2 & & 67 \\
\hline$>30$ & 12 & (42.9) & 16 & 57.1 & & 28 \\
\hline \multicolumn{7}{|l|}{ Sex: } \\
\hline Male & 83 & 46.1 & 97 & 53.9 & \multirow[t]{3}{*}{$P>0.05$} & 180 \\
\hline \multirow{2}{*}{\multicolumn{6}{|c|}{ Religion: }} & 120 \\
\hline & & & & & & \\
\hline Christian & 129 & 48.1 & 139 & 51.9 & \multirow[t]{3}{*}{$P>0.05$} & 268 \\
\hline & 15 & 46.9 & 17 & 53.1 & & 32 \\
\hline \multicolumn{6}{|l|}{$\begin{array}{l}\text { Having an } \\
\text { affected } \\
\text { relatives: }\end{array}$} & \\
\hline Yes & 69 & 56.1 & 54 & 43.9 & $P<0.05$ & 123 \\
\hline No & 75 & 42.4 & 102 & 57.6 & & 177 \\
\hline
\end{tabular}

